\title{
PENDUGAAN AKSI GEN PADA KARAKTER KOMPONEN HASIL DAN DAYA HASIL LATEKS BEBERAPA GENOTIPE KARET HASIL PERSILANGAN TETUA KLON IAN 873 X PN 3760
}

\author{
Estimation of Gene Action on Yield Component and Latex Yield Potential \\ Characters of Some Rubber Genotypes from Crossing Result of \\ IAN 873 X PN 3760 Parental Clones \\ SAYURANDI ${ }^{1 *}$ dan Sekar WOELAN ${ }^{2)}$ \\ ${ }^{1}$ Balai Penelitian Sungei Putih, Pusat Penelitian Karet \\ PO. Box 1415 Medan 20001 Sumatera Utara \\ *Email : sayurandi_sp@yahoo.com \\ ${ }^{2}$ Pusat Penelitian Karet \\ Jalan Salak Nomor 1 Bogor 16151 Jawa Barat
}

Diterima : 12 Agustus 2016 / Direvisi : 25 September 2016 / Disetujui : 22 Oktober 2016

\begin{abstract}
The objective of this research was to study the estimation of gene action on yield components and latex yield potential characters of rubber genotypes crossing results of IAN 873 X PN 3760 parental clones. The research was done at Seedling Evaluation Trial and Agronomy Laboratory, Sungei Putih Research Centre, Indonesian Rubber Research Institute located at Deli Serdang, North Sumatra Province. Exactly 35 genotypes and 2 parental clones were used in this research. The yield component characters which were observed namely girth, plant height, number of main branch, height of main branch, bark thickness, number of latex vessels, diameter of latex vessels, timber volume, and latex yield potential. The research results showed that nine characters which were observed had genetic variability with coefficient of phenotypic variation among 11.4 - 66.3\%. Based on gene action, complementary epistasis was found on girth, plant height, number of main branch, bark thickness, number of latex vessels rings, timber volume, and latex yield characters. It meant that seven characters were controlled by polygenes, while the dominant epistasis was found on high main branch and diameter of latex vessel rings characters. It meant that two characters were controlled by slightly gene.
\end{abstract}

Keywords: Hevea brasiliensis; yield component characters; latex yield potential; genetic variability; gene action.

\section{Abstrak}

Tujuan dari penelitian ini adalah untuk mempelajari pendugaan aksi gen karakter komponen hasil dan daya hasil lateks pada genotipe hasil persilangan klon IAN 873 X PN 3760. Penelitian dilakukan di Pengujian Evaluasi Semaian F1 dan Laboratorium Agronomi Balai Penelitian Sungei Putih, Pusat Penelitian Karet yang berada di Kabupaten Deli Serdang, Provinsi Sumatera Utara. Sebanyak 35 genotipe dan 2 tetua digunakan dalam penelitian ini. Karakter komponen hasil yang diamati yaitu lilit batang, tinggi tanaman, jumlah cabang pertama, tinggi cabang pertama, tebal kulit, jumlah ring pembuluh lateks, diameter sel pembuluh lateks, volume kayu, dan daya hasil lateks. Hasil penelitian menunjukkan bahwa terdapat keragaman genetik dari sembilan karakter yang diamati dengan nilai keragaman fenotipik antara 11,4-66,3\%. Berdasarkan aksi gen, epistasis komplementer ditemukan pada karakter lilit batang, tinggi tanaman, jumlah cabang utama, tebal kulit, jumlah ring pembuluh lateks, volume kayu, dan hasil lateks yang artinya ketujuh karakter tersebut sangat
\end{abstract}


dikendalikan oleh banyak gen, sedangkan epistasis dominan ditemukan pada karakter tinggi cabang utama dan diameter sel pembuluh lateks yang artinya bahwa kedua karakter tersebut dikendalikan oleh sedikit gen.

Kata kunci: Hevea brasiliensis; karakter komponen hasil; daya hasil lateks; keragaman genetik; aksi gen.

\section{PENDAHULUAN}

Keragaman genetik tanaman hasil persilangan buatan (hand pollination) merupakan modal dasar bagi pemulia tanaman untuk menyeleksi suatu individu tanaman. Variabilitas genetik tinggi yang terbentuk dari suatu program persilangan diharapkan akan diperoleh genotipe sesuai dengan karakter yang diinginkan oleh pemulia tanaman (Syukur, Sujiprihati, \& Yunianti, 2014). Khusus pada tanaman karet, peningkatan potensi hasil lateks masih merupakan tujuan utama para pemulia karet (Aidi-Daslin, 2012).

Pemulia karet saat ini sedang mengalami kendala dalam peningkatan potensi genetik tanaman. Keterbatasan keragaman genetik dengan menggunakan klon-klon yang ada (Generasi Wickham) sebagai tetua pada program persilangan berdampak terhadap lambatnya peningkatan hasil lateks yang disebabkan secara genetik tanaman pada generasi tersebut telah mengalami tekanan silang dalam (inbreed depression). Usaha yang dapat ditempuh untuk menghilangan efek inbreeding pada tanaman karet salah satunya adalah dengan melakukan kegiatan persilangan antar tetua tanaman yang memiliki hubungan kekerabatan genetik jauh. Hasil persilangan antar tanaman berkerabat jauh diharapkan akan membentuk keragaman genetik tinggi pada keturunannya, sehingga mempermudah melakukan seleksi pada karakter yang diinginkan (Woelan, Nisa, Chaidamsari, \& Irwansyah, 2015).

Persilangan tanaman berkerabat jauh telah dilakukan di Balai Penelitian Sungei Putih, Pusat Penelitian Karet yang salah satunya adalah menyilangkan klon karet IAN $873 \mathrm{X}$ PN 3760. Klon IAN 873 merupakan Generasi Wickham yang diseleksi di Instituto Agronomico do Norte yang merupakan hasil persilangan antara klon PB 86 x F 1717. Klon tersebut memiliki karakter potensi hasil lateks tinggi, namun pertumbuhan tanaman tergolong sedang. Klon PN 3760 merupakan hasil eksplorasi IRRDB tahun 1981 di Brasil yang memiliki karakter pertumbuhan tanaman cepat, namun potensi hasil lateks tergolong rendah. Karakter kedua tetua yang berbeda (distinct) tersebut dapat digunakan dalam mempelajari karakter turunan (F1) hasil persilangan dengan harapan menghasilkan keturunan yang mewarisi sifat dari kedua tetua (Aidi-Daslin, Suhendry, \& Azwar, 2000).

Keragaman genetik terdiri atas ragam genetik aditif, dominan, dan epistasis. Ragam genetik aditif adalah ragam genetik yang menyebabkan terjadinya kesamaan sifat di antara tetua dan turunannya. Fenotipe pada aksi gen aditif disebabkan penjumlahan dari masing-masing alel tanpa interaksi dengan alel lain (interaksi alelik atau non alelik), sedangkan pada aksi gen epistasis, fenotipe ditentukan oleh interaksi alel-alel dari lokus yang berbeda (Roy, 2000; Yunianti et al., 2007; Barrell et al., 2010).

Pada tanaman kedelai, toleransi kedelai terhadap tanah masam dikendalikan oleh aksi gen aditif yang juga dipengaruhi aksi gen epistasis. Kuswantoro, Basuki, dan Arsyad (2011) menyatakan bahwa pewarisan sifat jumlah polong kedelai di tanah masam dikendalikan oleh aksi gen epistasis. Sedangkan pada tanaman kacang panjang, kerentanan genetik kacang panjang terhadap penyakit mosaik dikendalikan oleh gen resesif yang saling berinteraksi (Kuswanto, Guritno, Soetopo, \& Kasno, 2004). Menurut Phillips (2008) aksi gen epistasis sangat berperan penting dalam menentukan karakter kualitatif dan kuantitatif pada suatu tanaman.

Karakter komponen hasil dan daya hasil lateks pada tanaman karet merupakan karakter kuantitatif yang dikendalikan oleh banyak gen minor (poligenik) dimana pengaruh masing-masing gen terhadap penampilan karakter fenotipenya kecil dan bersifat aditif. Gen-gen yang mengendalikan karakter kuantitatif tersebut bekerja secara 
bersama-sama sehingga secara genetik memiliki pengaruh lebih besar dibandingkan pengaruh lingkungan (Aquaah, 2007; Sobir \& Syukur, 2015). Banyaknya gen yang terlibat pada karakter kuantitatif menyebabkan pola sebaran karakter tersebut lebih bersifat kontinu, sedangkan jika membentuk sebaran diskrit maka karakter tersebut digolongkan sebagai karakter kualitatif. Karakter kualitatif tersebut pada umumnya dikendalikan oleh gen-gen mayor (monogenik). Pada kasus ini jumlah dan aksi gen yang mengendalikan suatu karakter komponen hasil dan daya hasil lateks dapat diketahui melalui perhitungan statistik dengan memanfaatkan nilai skewness dan kurtosis (Roy, 2000).

Skewness merupakan ukuran kemenjuluran kurva sebaran suatu populasi dan kurtosis merupakan ukuran kegemukan kurva. Jika nilai skewness mendekati nol atau sama dengan nol dapat diduga bahwa aksi gennya bersifat aditif, jika skewness bersifat negatif, maka aksi gen yang terlibat adalah aditif dengan pengaruh epitasis duplikat, sedangkan jika skewness bernilai positif, maka karakter tersebut dikendalikan oleh sifat aditif dengan pengaruh epistasis komplementer.

Pendugaan nilai kurtosis digunakan untuk menduga jumlah gen pengendalinya. Jika kurtosis bernilai > 3 maka sebarannya disebut leptokurtic dan karakter tersebut dikendalikan oleh sedikit gen (slightly gene), sedangkan jika kurtosis bernilai < 3 maka sebarannya disebut platykurtic dan karakter tersebut dikendalikan oleh banyak gen (polygenes) (Roy, 2000). Tujuan dari penelitian ini adalah untuk mempelajari pendugaan aksi gen karakter komponen hasil dan daya hasil lateks beberapa genotipe karet hasil persilangan klon IAN 873 X PN 3760.

\section{BAHAN DAN METODE}

Penelitian ini dilakukan di Pengujian Evaluasi Semaian F1 (SET $=$ Seedling Evaluation Trial) dan Laboratorium Agronomi, Balai Penelitian Sungei Putih, Pusat Penelitian Karet yang terletak di Kabupaten Deli Serdang, Provinsi Sumatera Utara. Lokasi penelitian berada pada ketinggian $\pm 54 \mathrm{~m}$ di atas permukaan laut (dpl). Materi genetik yang digunakan pada penelitian ini adalah 35 genotipe hasil persilangan IAN 873 X PN 3760 yaitu G32, G33, G36, G37, G39, G80, G79, G76, G75, G74, G73, G69, G68, G67, G57, G56, G55, G54, G53, G52, G50, G48, G47, G41, G81, G82, G83, G115, G120, G150, G146, G136, G135, G130,G128 dan dua tetua yaitu IAN 873 (P1) dan PN 3760 (P2). Genotipegenotipe tersebut ditanam pada tahun 2002. Masing-masing genotipe ditanam sebanyak satu tanaman dengan jarak tanam $2 \mathrm{~m} \times 2 \mathrm{~m}$, sedangkan klon IAN 873 diamati pada penelitian ini berasal dari kebun komersial dan klon PN 3760 diamati di kebun koleksi plasma nutfah IRRDB 1981.

Pengamatan dilakukan pada masing-masing genotipe berumur sembilan tahun yang meliputi: lilit batang tanaman, tinggi tanaman, tinggi batang bebas cabang, jumlah cabang primer, tebal kulit, jumlah ring pembuluh lateks, diameter sel pembuluh lateks, volume kayu, dan hasil lateks. Data hasil penelitian dianalisis menggunakan statistik dengan memanfaatkan Program MINITAB Ver. 16 untuk mendapatkan nilai tengah, minimum, maksimum, simpangan baku dan koefisien keragaman fenotipik (KKF). Sebaran data setiap karakter pada populasi turunan F1 dianalisis dengan menggunakan uji kenormalan kurva. Analisis ini digunakan untuk menduga jumlah dan aksi gen yang mengendalikan suatu karakter tertentu. Pendugaan aksi gen yang mengendalikan karakter yang diamati dilakukan melalui analisis skewness dan kurtosis (Roy, 2000) dengan memanfaatkan Program MINITAB Ver. 16.

Nilai skewness (Sk) dihitung dengan menggunakan rumus matematika sebagai berikut:

$$
S k=\frac{n}{(n-1)(n-2)} \sum\left(\frac{x_{j}-\bar{x}}{s}\right)^{3}
$$

Sedangkan nilai kurtosis dihitung dengan rumus sebagai berikut:

$K c=\left\{\frac{n(n+1)}{(n-1)(n-2)(n-3)} \sum\left(\frac{x_{i}-\bar{x}}{s}\right)^{4}\right\}-\frac{3(n-1)^{2}}{(n-2)(n-3)}$ 
Keterangan (Remarks):

n: Jumlah tanaman

$\mathrm{x}_{\mathrm{i}}$ : Parameter $\mathrm{x}$ pada nilai ke- $\mathrm{i}$

$\overline{\mathrm{x}}$ : Nilai rata-rata parameter

s: Standar deviasi

Dimana,

- Nilai skewness = 0 sebaran normal: aksi gen aditif

- Nilai skewness < 0 sebaran tidak normal: aksi gen aditif dan terdapat pengaruh epistasis duplikat

- Nilai skewness > 0 sebaran tidak normal: aksi gen aditif dan terdapat pengaruh epistasis komplementer

- Nilai kurtosis < 3 sebaran platykurtic: karakter dikendalikan oleh banyak gen

- Nilai kurtosis > 3 sebaran leptokurtic: karakter dikendalikan oleh sedikit gen

\section{HASIL DAN PEMBAHASAN}

\section{Keragaan Karakter Komponen Hasil dan Daya Hasil Lateks}

Analisis statistik terhadap karakter komponen hasil dan daya hasil lateks beberapa genotipe hasil persilangan IAN 873 X PN 3760 disajikan pada Tabel 1. Hasil pengamatan menunjukkan bahwa karakter jumlah cabang utama dan volume kayu memiliki keragaman fenotipik yang paling tinggi dengan nilai koefisien keragaman fenotipik (KKF) yaitu masing - masing sebesar $66,3 \%$ dan $64,2 \%$.

Karakter komponen hasil lainnya yang diamati menunjukkan keragaman fenotipik berkisar antara 11,4 - 36,2\%. Karakter diameter sel pembuluh lateks menunjukkan keragaman fenotipik yang paling rendah $(\mathrm{KKF}=11,4 \%)$ dengan nilai tengah sebesar $27 \mu \mathrm{m}$. Hal ini mengindikasikan bahwa karakter diameter sel pembuluh lateks antar genotipe lebih seragam dibandingkan dengan karakter lainnya. Koefisien keragaman yang rendah pada diameter sel pembuluh lateks juga sudah pernah dilaporkan pada penelitian sebelumnya (Novalina et al., 2008; Woelan et al., 2014).

Terdapatnya keragaman karakter komponen hasil dan daya hasil antar genotipe diduga lebih diakibatkan oleh faktor genetik. Hal ini dapat dipahami mengingat tetua betina dan tetua jantan memiliki kekerabatan genetik yang jauh
(Oktavia et al., 2010; Sayurandi \& AidiDaslin, 2011). Klon IAN 873 yang merupakan tetua betina berasal dari Populasi Wickham pada tahun 1876, sedangkan klon PN 3760 merupakan hasil ekspedisi IRRDB pada tahun 1981. Selain itu, diduga juga diakibatkan oleh sifat heterozigot heterogen pada hasil keturunan tanaman karet yang dapat diketahui dari nilai kisaran genotipe dan nilai KKF yang cukup beragam. Menurut Novalina (2009), keragaman genetik yang jauh antara tetua Populasi Wickham dan IRRDB 1981 mengakibatkan gen-gen yang terlibat pada penampilan suatu karakter tanaman bersegregasi pada populasi turunan pertama.

Tabel 1 menunjukkan bahwa salah satu genotipe memiliki jumlah cabang primer melebihi nilai rata-rata kedua tetua dengan jumlah cabang primer sebanyak 7 cabang, demikian halnya dengan diameter sel pembuluh lateks salah satu genotipe memiliki diameter sel pembuluh lateks $(34,4$ $\mu \mathrm{m})$ melebihi nilai rata-rata kedua tetua. Ukuran lilit batang dan hasil lateks untuk semua genotipe memiliki nilai tengah jauh lebih rendah dibandingkan dengan kedua tetua. Berdasarkan karakter pertumbuhan lilit batang dan hasil lateks genotipe hasil persilangan tersebut menunjukkan bahwa belum diperoleh segregan-segregan potensial untuk dikembangkan lebih lanjut. Woelan et al (2014) melaporkan bahwa hasil persilangan tetua berkerabat jauh yakni klon RRIM 600 X PN 1546 pada pengujian SET belum berhasil menemukan segregan potensial yang dapat dikembangkan sebagai genotipe penghasil lateks tinggi.

Novalina (2009) juga telah melaporkan bahwa persilangan antara klon PB 260 X PN 7 dan PB 260 X PN 7111 belum memberikan hasil nyata terhadap perbaikan potensi hasil lateks pada genotipe F1. Demikian halnya dalam penelitian ini masih belum memberikan kemajuan seleksi terhadap genotipe $\mathrm{F} 1$ hasil persilangan klon IAN 873 X PN 3760. Dari beberapa hasil penelitian yang telah dilaporkan ternyata genotipe $\mathrm{F} 1$ hasil persilangan antara populasi Wickham dengan genotipe IRRDB 1981 masih jauh dari harapan untuk memperoleh kandidat klon karet unggul. Potensi hasil karet kering genotipe-genotipe tersebut masih jauh di bawah potensi hasil karet kering pada klon-klon yang sudah dibudidayakan saat ini (Sayurandi \& Woelan, 2015). 
Tabel 1. Nilai tengah karakter pertumbuhan, anatomi kulit, dan hasil lateks dari beberapa genotipe hasil persilangan IAN 873 X PN 3760 pada umur 9 tahun

Table 1. Mean value of growth, bark anatomy, and latex yield characters of some genotype crossing result of IAN 873 X PN 3760 parental clones at 9 years old

\begin{tabular}{lcccccc}
\hline \multicolumn{1}{c}{$\begin{array}{c}\text { Karakter } \\
\text { Characters }\end{array}$} & P1 & P2 & $\begin{array}{c}\text { Nilai tengah } \\
\text { genotipe } \\
\text { Mean value } \\
\text { of genotype }\end{array}$ & $\begin{array}{c}\text { Kisaran } \\
\text { genotipe } \\
\text { Genotype } \\
\text { range }\end{array}$ & $\sigma$ & $\begin{array}{c}\text { KKF } \\
(\%)\end{array}$ \\
\hline Lilit batang $(\mathrm{cm})$ & 58,0 & 85,0 & 42,3 & $21,5-64,5$ & 11,6 & 27,5 \\
Tinggi tanaman $(\mathrm{m})$ & 18,5 & 28,0 & 11,7 & $5,5-14,5$ & 2,2 & 20,1 \\
Jumlah cabang primer & 4,0 & 3,0 & 2,0 & $1,0-7,0$ & 1,3 & 66,3 \\
Tinggi cabang utama $(\mathrm{m})$ & 7,2 & 12,4 & 6,7 & $0,7-10,0$ & 2,4 & 36,2 \\
Tebal kulit $(\mathrm{mm})$ & 7,0 & 8,0 & 3,9 & $2,5-5,0$ & 0,7 & 17,7 \\
Jumlah ring pembuluh lateks & 11,0 & 5,0 & 4,6 & $3,0-6,5$ & 0,9 & 22,2 \\
Diameter sel pembuluh lateks $(\mu \mathrm{m})$ & 29,8 & 18,6 & 27,0 & $16,9-34,4$ & 3,1 & 11,4 \\
Volume kayu $\left(\mathrm{m}^{3} /\right.$ pohon) & 0,2 & 0,4 & 0,1 & $0,01-0,29$ & 0,1 & 64,2 \\
Hasil lateks $(\mathrm{g} / \mathrm{p} / \mathrm{s})$ & 35,0 & 11,5 & 13,7 & $10,5-20,7$ & 2,3 & 27,7 \\
\hline
\end{tabular}

$\mathrm{P} 1$ = tetua betina IAN 873 (female parent); P2= tetua jantan PN 3760 (male parent); $\sigma=$ simpangan baku (standard deviation); KKF = koefisien keragaman fenotipe (coefficient of phenotypic variation)

Klon karet hasil pemuliaan yang berkembang saat ini seperti klon seri PB, seri RRIM, dan seri IRR memiliki hasil lateks $(\mathrm{g} / \mathrm{p} / \mathrm{s})$ sebesar $\pm 25 \mathrm{~g}$ pada penyadapan tahun pertama (TM-1) dan terus meningkat sejalan dengan bertambahnya umur tanaman, sedangkan genotipe-genotipe hasil persilangan antara klon IAN 873 dan PN 3760 yang diamati pada tahun pertama sadap (TM-1) memiliki rata-rata hasil lateks hanya sebesar $13,7 \mathrm{~g}$ dengan kisaran antara $10,5-20,7 \mathrm{~g}$.
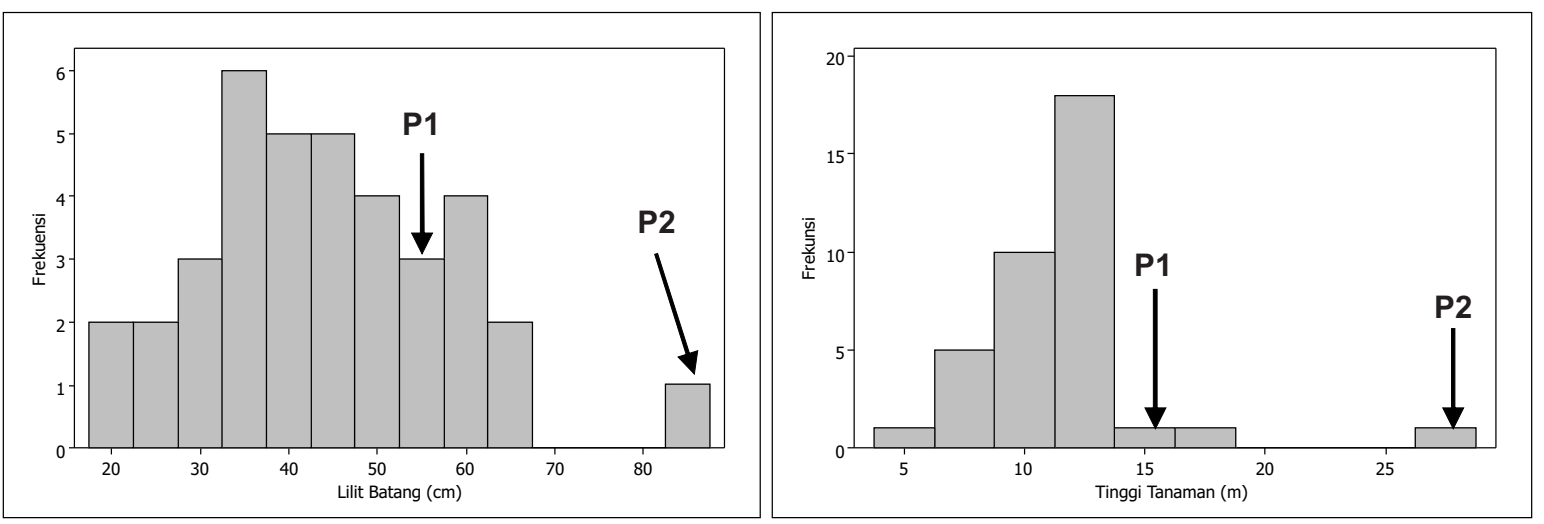

Gambar 1. Pola sebaran data ukuran lilit batang dan tinggi tanaman pada 35 genotipe hasil persilangan tetua klon IAN 873 (P1) X PN 3760 (P2)

Figure 1. Distribution pattern data of girth and plant high of 35 genotypes crossing result of IAN 873 (P1)XPN 3760 (P2) parental clones. 

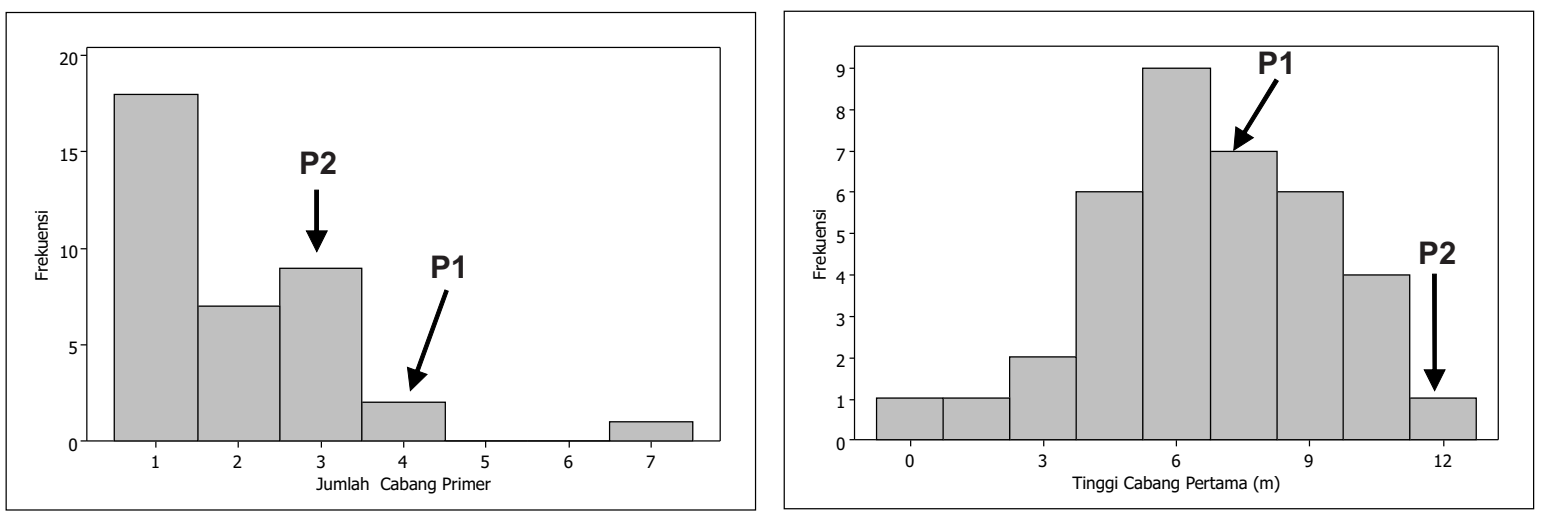

Gambar 2. Pola sebaran data jumlah cabang primer dan tinggi cabang pertama pada 35 genotipe hasil persilangan tetua klon IAN 873 (P1) X PN 3760 (P2)

Figure 2. Distribution pattern data of number of main branch and high main branch of 35 genotypes crossing result of IAN 873 (P1)XPN 3760 (P2) parental clones.
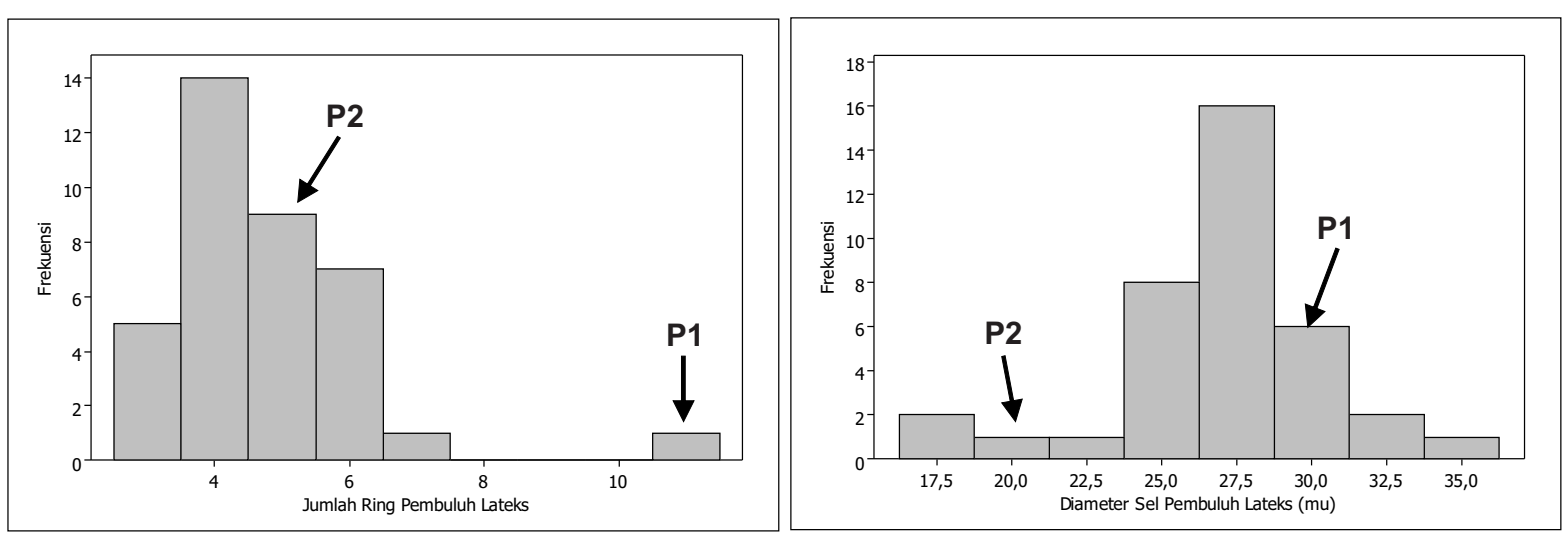

Gambar 3. Pola sebaran data jumlah ring pembuluh lateks dan diameter sel pembuluh lateks pada 35 genotipe hasil persilangan tetua klon IAN 873 (P1) X PN 3760 (P2)

Figure 3. Distribution pattern data of number oflatex vessels and diameter of latex vessel of 35 genotypes crossing result of IAN 873 (P1) XPN 3760 (P2) parental clones.
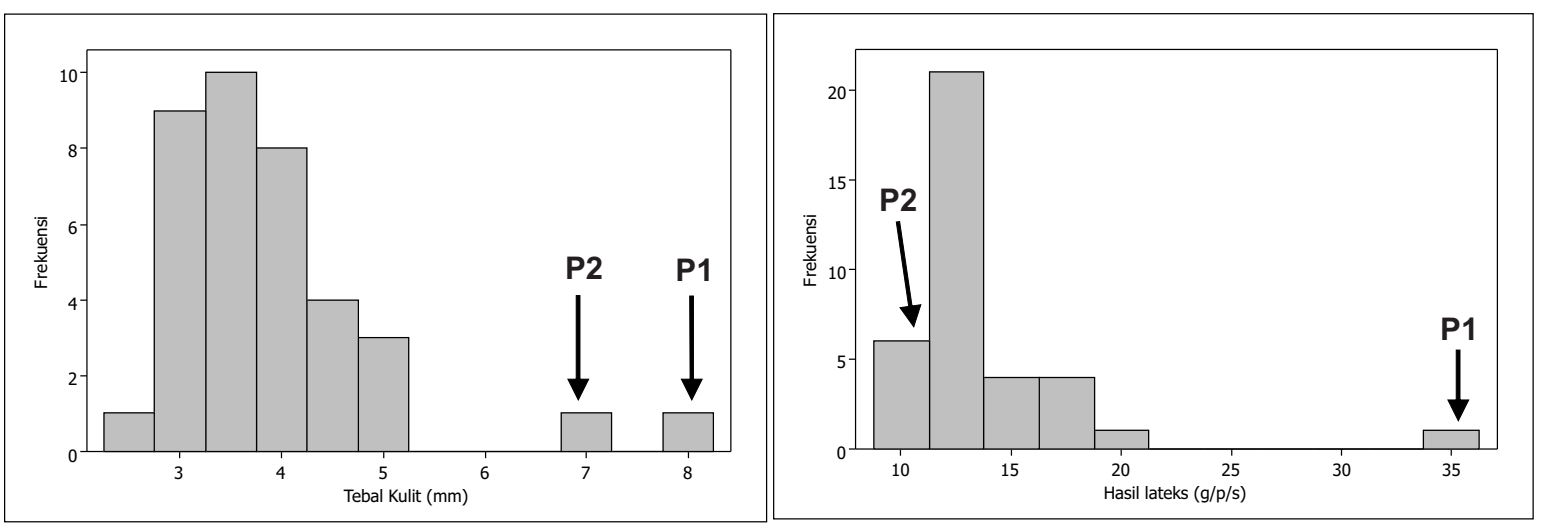

Gambar 4. Pola sebaran data tebal kulit dan hasil lateks pada 35 genotipe hasil persilangan tetua klon IAN 873 (P1) X PN 3760 (P2)

Figure 4. Distribution pattern data of bark thickness and latex yield of 35 genotypes crossing result of IAN 873 (P1)X PN 3760 (P2) parental clones. 


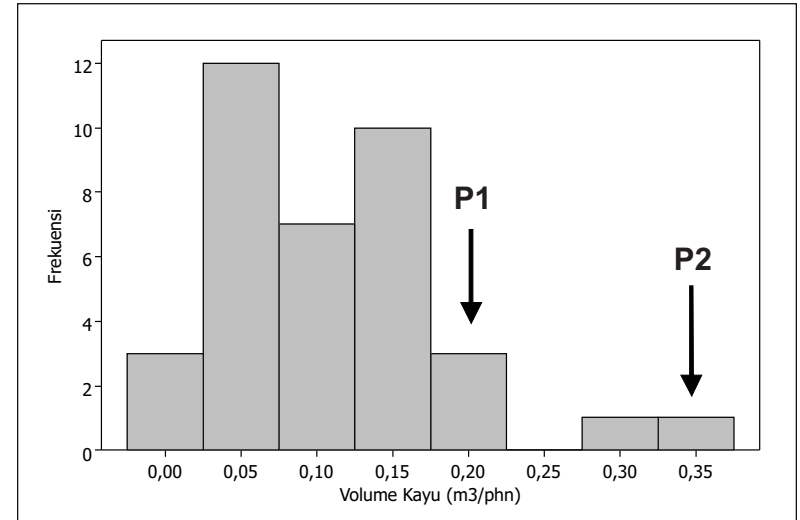

Gambar 5. Pola sebaran data volume kayu pada 35 genotipe hasil persilangan tetua klon IAN 873 (P1) X PN 3760 (P2)

Figure 5. Distribution pattern data of timber volume of 35 genotypes crossing result of IAN 873 (P1) XPN 3760 (P2) parental clones.

Terdapat karakter komponen hasil yang memiliki nilai karakter diantara kedua tetua yaitu pada karakter diameter sel pembuluh lateks. Menurut Jambormias (2014), karakter kuantitatif pada tanaman yang penyebarannya menjulur ke kiri atau ke kanan menunjukkan adanya pengaruh lingkungan, interaksi genotipe $\mathrm{x}$ lingkungan, pautan gen atau epistasis.

Epistasis adalah interaksi antara dua gen atau lebih dari lokus yang berbeda dalam membentuk suatu fenotipe (Saxena, Saxena, Kumar, \& Varshney, 2012). Epistasis terdiri dari epistasis komplementer dan epistasis duplikat. Epistasis komplementer adalah interaksi gen dimana fungsi suatu gen akan diperlukan oleh gen lain untuk membentuk suatu fenotipe, sedangkan epistasis duplikat adalah interaksi yang hanya jika dua gen menghasilkan bahan yang sama untuk membentuk fenotipe yang sama (Klug, Cummings, Spencer, \& Palladino, 2011).

Tabel 2. Pendugaan aksi gen dan jumlah gen karakter agronomi pada 35 genotipe hasil persilangan klon IAN 873 X PN 3760.

Table 2. Gene action estimation and number of genes on agronomy character of 35 genotypes crossing result of IAN 873 XPN 3760 rubber parental clones

\begin{tabular}{lcccc}
\hline \multicolumn{1}{c}{ Karakter } & Skewness & Aksi gen & Jumlah gen \\
\multicolumn{1}{c}{ Characters } & & Gene action & Kurtosis & $\begin{array}{c}\text { Number of } \\
\text { genes }\end{array}$ \\
& & & & Banyak gen \\
Lilit batang $(\mathrm{cm})$ & 0,66 & Epistasis komplementer & 0,91 & Sedikit gen \\
Tinggi tanaman $(\mathrm{m})$ & 2,33 & Epistasis komplementer & 9,97 & Sedikit gen \\
Jumlah cabang primer & 1,88 & Epistasis komplementer & 4,81 & Banyak gen \\
Tinggi cabang utama $(\mathrm{m})$ & $-0,27$ & Epistasis dominan & 0,30 & Sedikit gen \\
Tebal kulit $(\mathrm{mm})$ & 2,13 & Epistasis komplementer & 5,90 & Sedikit gen \\
Jumlah ring pembuluh lateks & 2,46 & Epistasis komplementer & 9,97 & Banyak gen \\
Diameter sel pembuluh lateks $(\mu \mathrm{m})$ & $-0,95$ & Epistasis dominan & 2,51 & Banyak gen \\
Volume kayu $\left(\mathrm{m}^{3} /\right.$ pohon) & 1,13 & Epistasis komplementer & 1,62 & Banyak gen \\
Hasil lateks $(\mathrm{g} / \mathrm{p} / \mathrm{s})$ & 0,70 & Epistasis komplementer & 1,71 & Bany \\
\hline
\end{tabular}


Nilai skewness dan kurtosis untuk menduga aksi gen dan jumlah gen karakter agronomi dari 35 genotipe hasil persilangan IAN $873 \mathrm{X}$ PN 3760 disajikan pada Tabel 2.

Tabel 2 menunjukkan bahwa karakter lilit batang, tinggi tanaman, jumlah cabang, tebal kulit, jumlah ring pembuluh lateks, volume kayu dan hasil lateks memiliki nilai skewness $>0$. Nilai skewness $>0$ menunjukkan bahwa karakter-karakter tersebut memiliki sebaran tidak normal dan aksi gen yang mengendalikan karakter tersebut bersifat epistasis komplementer yang artinya karakter tersebut dikendalikan oleh banyak gen yang berbeda lokus berinteraksi dalam menghasilkan suatu fenotipe tertentu. Aksi gen dari suatu lokus dapat menutupi aksi gen pada lokus yang lain. Penampilan suatu karakter atau fenotipe adalah hasil suatu proses metabolisme yang pada setiap tahapannya melibatkan kerja suatu gen, oleh karena itu diperlukan sederetan gen (Sobir \& Syukur, 2015).

Karakter tinggi cabang utama dan diameter sel pembuluh lateks memiliki nilai skewness < 0 . Kedua karakter tersebut memiliki sebaran tidak normal dengan aksi gen bersifat epistasis dominan. Hubungan antara ciri-ciri suatu sifat tidak selalu memiliki hubungan dominan-resesif. Pada penelitian ini menunjukkan bahwa ciri yang muncul pada genotipe hasil persilangan ternyata bukan merupakan ciri dari salah satu tetua, melainkan campuran dari kedua tetua yang memiliki hubungan kodominan sebab tidak ditemukannya alel dominanresesif, kedua alel berinteraksi dan berekspresi menghasilkan fenotipe baru yang berbeda dengan tetuanya (Susanto, 2011; Sobir \& Syukur, 2015).

Tabel 2 menunjukkan nilai kurtosis masing-masing karakter agronomi. Karakter lilit batang, tinggi cabang utama, diameter sel pembuluh lateks, volume kayu, dan hasil lateks memiliki nilai kurtosis < 3. Nilai kurtosis < 3 menunjukkan bahwa karakterkarakter tersebut memiliki grafik sebaran platykurtic yang berarti karakter tersebut dikendalikan oleh banyak gen (poligenik). Karakter tinggi tanaman, jumlah cabang, tebal kulit, dan jumlah ring pembuluh lateks memiliki nilai kurtosis $>3$, grafik dengan nilai kurtosis $>3$ memiliki sebaran leptokurtic yang berarti karakter-karakter tersebut dikendalikan oleh sedikit gen. Menurut Mather dan Jinks (1977) bahwa grafik tidak menyebar normal terjadi akibat gen-gen non aditif yang mengendalikan keragaman pada populasi dipengaruhi oleh adanya pautan, adanya keterlibatan gen mayor, dan pengaruh lingkungan yang besar.

Berdasarkan penelitian yang telah dilakukan diketahui bahwa perwarisan karakter kuantitatif yang diamati pada populasi genotipe yang berasal dari persilangan klon IAN 873 X PN 3760 tidak diwariskan secara sederhana melainkan dipengaruhi oleh banyak gen. Menurut Mather dan Jinks (1977), karakter kuantitatif dikendalikan oleh banyak gen (poligenik), sedangkan menurut Roy (2000), hampir semua karakter kuantitatif yang dipelajari dikendalikan secara poligenik dengan aksi gen aditif dengan pengaruh epistasis duplikat, epistasis aditif maupun epistasis komplementer. Terdapatnya epistasis menegaskan bahwa perlu lebih banyak individu-individu segregan yang ditanam pada generasi berikutnya sehingga akan menghasilkan genotipe harapan yang lebih potensial. Selain itu, pengaruh epistasis komplementer dan duplikat akan menurun seiring dengan lanjutnya generasi bersegregasi.

\section{KESIMPULAN}

Terdapat keragaman karakter komponen hasil dan daya hasil lateks genotipe hasil persilangan klon IAN $873 \mathrm{X}$ PN 3760 dengan nilai KKF berkisar antara $11,4-66,3 \%$. Berdasarkan pendugaan aksi gen diperoleh epistasis komplementer pada karakter lilit batang, tinggi tanaman, jumlah cabang utama, tebal kulit, jumlah ring pembuluh lateks, volume kayu, dan hasil lateks yang artinya ketujuh karakter tersebut sangat dikendalikan oleh banyak gen, sedangkan epistasis dominan terdapat pada karakter tinggi cabang utama dan diameter sel pembuluh lateks yang artinya bahwa kedua karakter tersebut dikendalikan oleh sedikit gen. Untuk mengetahui informasi yang lebih mendalam terhadap genotipe-genotipe tersebut, maka perlu dilakukan pengujian pada skala yang lebih luas. 


\section{UCAPAN TERIMA KASIH}

Ucapan terima kasih dan penghargaan tinggi disampaikan kepada Balai Penelitian Sungei Putih, Pusat Penelitian Karet atas bantuan dana riset melalui program In House Research TA 2015 serta kepada para Teknisi Penelitian a.n Indra Gunawan, Ervina, dan Gani atas bantuan dan kerjasama selama pelaksanaan kegiatan penelitian sehingga dapat berjalan dengan baik dan selesai tepat waktu.

\section{DAFTAR PUSTAKA}

Aidi-Daslin., Suhendry, I., \& Azwar, R. (2000). Growth characteristic and yield performance or recommended clones in commercial planting. Proceedings International Rubber Conference and IRRDB Symposium 2000 (p. 150-158). Medan - Indonesia: IRRI-IRRDB.

Aidi-Daslin. (2012). Evaluasi pengujian lanjutan klon karet IRR seri 120-140. Jurnal Penelitian Karet, 30(2), 65-74.

Aquaah, G. (2007). Principles of Plant Genetics and Breeding. USA: Blackwell Publishing.

Barrell, P. J., Wakelin, A. M., Gatehouse, M. L., Lister, C. E., \& Conner, A. J. (2010). Inheritance and epistasis of loci influencing caratenoid content in petal and pollen color variants of california poppy. J. Heredity, 101(6), 750-756. Doi: $10.1093 /$ jhered/esq079.

Jambormias, E. (2014). Analisis genetik dan segregasi transgresif berbasis informasi kekerabatan untuk potensi hasil dan panen serempak kacang hijau (Disertasi), Institut Pertanian Bogor, Indonesia.

Klug, W. S., Cummings, M. R., Spencer, C. A., \& Palladino, M. A. (2011). Concepts of Genetict. California, USA: Pearson Press.
Kuswanto, B., Guritno, L., Soetopo., \& Kasno, A. (2004). Pendugaan jumlah dan model aksi gen ketahanan kacang panjang (Vigna sesquipedalis L. Fruwirth) terhadap cowpea aphid borne mosaiv virus. J. Agrivita, XXVI (3), 262-270.

Kuswantoro, H., Basuki, N., \& Arsyad, D. M. (2011). Inheritance of soybean pod number trait on acid soil. J. Agrivita, 33 ( 3 ) , $119 \begin{array}{llll} & 1 & 9 & 6\end{array}$. Doi:10.17503/agrivita.v3312.53

Mather, F. R. S. S. K., \& Jinks, F. R. S. J. (1977). Introduction to Biometrichal Genetics, the study of continous variation $3^{\text {rd }}$ edition. New York, USA: Chapman and Hall.

Novalina, Jusuf, M., Wattimena, G. A., Suharsono, Sumarmadji, \& AidiDaslin. (2008). Keragaan dan hubungan berbagai komponen hasil tanaman karet (Hevea brasiliensis Muell. Arg.) pada dua populasi hasil persilangan PB 260 dengan PN. Bul. Agron, 36(2), 152-159.

Novalina. (2009). Deteksi marka genetik yang terpaut dengan komponen produksi lateks pada tanaman karet (Hevea brasiliensis Muell Arg.) melalui Pemetaan QTL (Disertasi), Institut Pertanian Bogor, Indonesia.

Oktavia, F., Lasminingsih, M., \& Kuswanhadi. (2010). Hubungan kekerabatan genetik antar klon karet sebagai dasar pemilihan tetua untuk mendapatkan klon unggul lateks kayu. Jurnal Penelitian Karet, 28(2), 110.

Phillips, P.C. (2008). Epistasis, the essential role of gene interactions in the structure and evolution of genetic systems. Nat. Rev. Genet, 9(11), 85567. Doi: $10.1038 / \mathrm{nrg} 2452$.

Roy, D. (2000). Plant breeding analysis and exploitation of variation. New Delhi, India: Narosa Publishing House. 
Saxena, K. B., Saxena, R. K., Kumar, R. V., \& Varshney, R. K. (2012). Evidance of a unique inter-allelic epistasis interaction for seed coat color in pigeonpea (Cajanus cajan (L.) Millspaugh\}. J. Euphytica, 186(3), 813816. Doi: 10.1007/s10681-011-0610$z$.

Sayurandi., \& Aidi-Daslin. (2011). Heterosis dan heritabilitas pada progeni $\mathrm{F} 1$ hasil persilangan kekerabatan jauh tanaman karet. Jurnal Penelitian Karet, 29(1), 1-15.

Sayurandi., \& Woelan, S. (2015). Keragaan dan potensi hasil karet kering dari beberapa genotipe hasil persilangan antar tetua tanaman berkerabat jauh. Jurnal Penelitian Karet, 33(1), 1-10.

Sobir., \& Syukur, M. (2015). Genetika Tanaman. Bogor, Indonesia: IPB Press.

Susanto, A. H. (2011). Genetika. Yogyakarta, Indonesia: Graha Ilmu Press.
Syukur, M., Sujiprihati, S., \& Yunianti, R. (2014). Teknik pemuliaan tanaman. Jakarta, Indonesia: Penebar Swadaya.

Woelan, S., Nisa, C., Chaidamsari, T., \& Irwansyah, E. (2015). Analisis genetik populasi hasil persilangan klon RRIM 600 dengan genotipe plasma nutafh 1981. Jurnal Penelitian Karet, 33(2): 101-120.

Woelan, S., Sayurandi., \& Irwansyah, E. (2014). Keragaman genetic tanaman karet (Hevea brasiliensis Muell Arg) dari hasil persilangan interspesifik. Jurnal Penelitian Karet, 32(2), 109-121.

Yunianti, R., Satrosumarjo, S., Sujiprihati, S., Surahman, M., \& Hidayat, S. H. (2007). Ketahanan 22 genotipe cabai (Capsicum spp) terhadap Phytoptora capsici Leonian dan keragaman genetiknya. Bul. Agron., 35(2), 103111. 